\title{
First detection of the Nearctic parasitoid species Trichopoda pennipes (Fabricius) (Diptera: Tachinidae) in Egypt
}

\author{
Magdi Shaaban Ali El-Hawagry ${ }^{1 *}$ (D), Ayman Mohey Eldin Ebrahim² and Maha Salah Eldin Nada ${ }^{3}$
}

\begin{abstract}
Specimens of the feather-legged fly, Trichopoda pennipes (Fabricius) (Diptera: Tachinidae), which parasitize adults of the southern green stink bug Nezara viridula (L.) (Hemiptera: Pentatomidae), have been detected in Giza, Egypt. This is the first record of this Nearctic species with its genus (Trichopoda) and its tribe (Gymnosomatini) in Egypt. T. pennipes is known as an endoparasitoid of many true bug hosts, the pests of various crops, and it could have a potentiality to control these pests in addition to N. viridula, which is known to be its principal host. Taxonomy and diagnosis of the detected parasitoid species in addition to a checklist of the subfamily Phasiinae in Egypt are provided. Colored photographs of the parasitoid larval and adult stages and parasitized host are provided as well.
\end{abstract}

Keywords: New record, Trichopoda pennipes, Nezara viridula, Egypt

\section{Background}

Flies of the family Tachinidae are an important group of endoparasitoids in their larval stage, and all their hosts are of the arthropods, almost exclusively other insects, including important insect pests in agriculture and forestry. There are four subfamilies traditionally recognized in the family Tachinidae, namely, Dexiinae, Exoristinae, Phasiinae, and Tachininae (El-Hawagry 2018). Of these, the subfamily Phasiinae is known to comprise species which attack true bugs (Heteroptera) (Arnaud 1978).

In Egypt, the subfamily Phasiinae is known as comprising only seven species in three tribes, namely, Cylindromyiini, Leucostomatini, and Phasiini (El-Hawagry 2018). The tribe Gymnosomatini comprising the species detected in the present study, Trichopoda pennipes (Fabricius 1781), has not previously been recorded from Egypt.

Species of the genus Trichopoda (Berthold 1827) are commonly known as the "feather-legged flies" because of the prominent fringe of feather-like setae on their hind legs. One of these species, T. pennipes (Fabricius 1781), is an endoparasitoid of late-instar nymph and adult of the southern green stink bug, Nezara viridula (L.) (Todd 1989). It is native to the Nearctic region; however, it was

\footnotetext{
* Correspondence: elhawagry@gmail.com; elhawagry@sci.cu.edu.eg 'Entomology Department, Faculty of Science, Cairo University, Giza, Egypt Full list of author information is available at the end of the article
}

introduced from its native fauna, precisely from the USA into some Australasian countries to combat true bugs, especially the southern green stink bug, $N$. viridula (Waterhouse 1998). Although it has been successfully established in Hawaii reporting a 100\% rate of parasitism of N. viridula (Davis 1964; Michael 1981), T. pennipes has failed to become established in Australia as it was introduced there in the 1940s and 1950s, then more recently in 1990s (Waterhouse 1998). Moreover, attempts to establish T. pennipes in Antigua (Cock 1985), Fiji (O'Connor 1950), New Zealand (Clausen 1978), Papua New Guinea (Waterhouse and Norris 1987), Solomon Islands (O'Connor 1950), and South Africa (Bennett 1990) have also failed. Failure to establish Trichopoda spp. may have been due in part to difficulties with rearing sufficient numbers of parasitoids for release (Michael 1981).

In the Old World, T. pennipes has been accidentally introduced to Italy, where it was first recorded near Rome in 1988, and it is now well established as an important natural enemy of $N$. viridula in this country (Colazza et al. 1996). In following years, it was recorded from several other Mediterranean and European countries: Spain (Peris 1998; Tschorsnig et al. 2000), France (Tschorsnig et al. 2000; Galerie-insecte 2015), Slovenia (De Groot et al. 2007), the Netherlands (Zeegers 2010), 
Israel (Freidberg et al. 2011), Albania (Tschorsnig et al. 2012), Croatia (Bystrowski 2012), Hungary (Sándor 2014), Switzerland (Obrecht 2014; Pétremand et al. 2015), and Portugal (Pétremand et al. 2015).

Egypt, as a part of the Great Desert Belt, is characterized by a warm and almost rainless climate and has a greater affiliation to the Palearctic region except for the Gebel Elba, its southeastern triangle, which has a greater affiliation to the Afrotropical region (El-Hawagry and Gilbert 2014; ElHawagry 2017). However, and according to the present study, T. pennipes seems to be established in Egypt.

In addition to Pentatomidae (genera Nezara, Acrosternum, Euschistus, Halyomorpha, Murgantia, Plautia, and Thyanta), T. pennipes was recorded to have a broad host range including Coreidae (genera Acanthocephala, Anasa, Archimerus, Chelinidea, Euthochtha, and Leptoglossus), Largidae (genus Largus), and Scutelleridae (genus Coleotichus) (Arnaud 1978; Rice et al. 2014).

In optimal climatic conditions, T. pennipes shows $2-3$ generations per year. The female lays one or more whitish plano-convex, non-incubated eggs upon the body wall of the adult, or occasionally on late nymphal instar of the bug, and attach these eggs firmly to the body wall. The majority of the eggs are found on the sides of the thorax (Worthley 1924; Salerno et al. 2002). Each female produces several hundred eggs during its lifespan (Pétremand et al. 2015). After hatching, newborn larva bores the host bug tegument entering its body and feeds on its body fluids for about 2 weeks. The host bug usually dies after the infection, and mature larvae emerge through its anal extremity and enter the upper soil layer to form a dark-brownish puparium (Worthley 1924). Pupation usually requires about 2-4 weeks (Cargnus et al. 2011).

Adults of T. pennipes mostly are nectar feeders. Larvae overwinter within the host bug and emerge in the following late spring or early summer (Worthley 1924).

\section{Materials and methods}

This study is based on 6 adult individuals (4 males and 2 females) of $T$. pennipes. Two of these individuals were found in November 2019 within a cage in which the southern green stink bug $N$. viridula was reared at the Faculty of Agriculture, Cairo University, Giza, Egypt. The reared bugs were originally collected from a field cultivated with bean at the farm of "Faculty of Agriculture, Cairo University, Giza" in October 2018. Two parasitized adults (Fig. 1a, b) and one nymph of the bug were detected in the cage as well. The parasitized bug $\mathrm{a}$

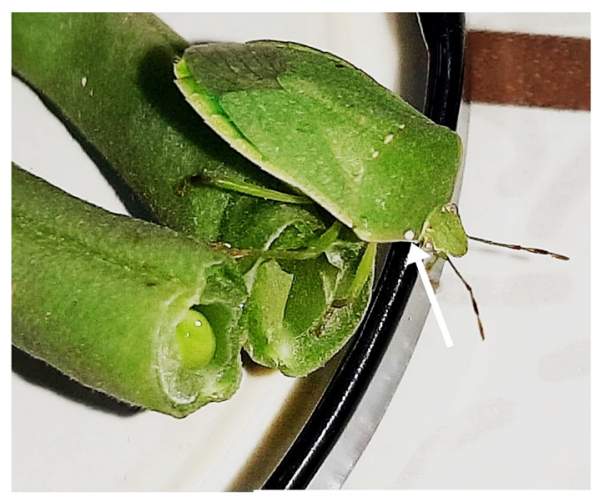

c

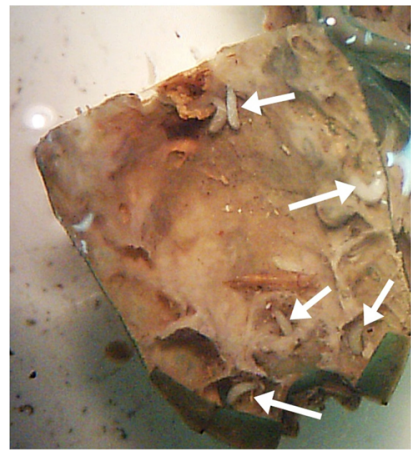

b

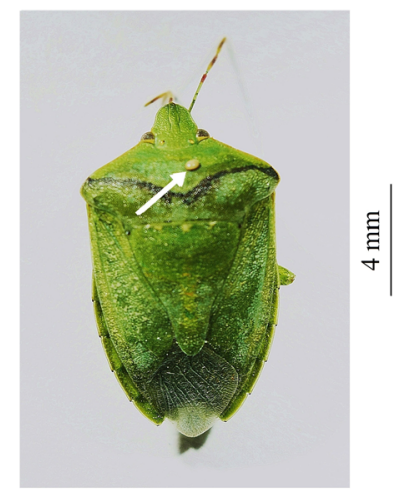

d

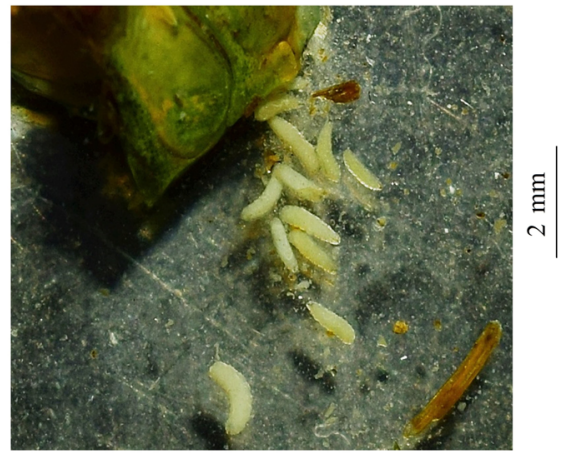

Fig. 1 a, b Adult specimens of Nezara viridula (L.) bearing eggs of Trichopoda pennipes on the pronotum. $\mathbf{c}$ Larvae of T. pennipes inside a dissected $N$. viridula specimen. $\mathbf{d}$ Larvae of $T$. pennipes released from a dissected $N$. viridula specimen 
individuals were transferred to a separate cage at the same laboratory conditions to verify that they are parasitized by the same parasitoid. After about 3 weeks, another 4 individuals of the same parasitoid emerged in the cage. One of the parasitized bugs was dissected to check the larvae of the parasitoid within it (Fig. 1c, d). The parasitoid larvae, adults, and the parasitized hosts were photographed. Four adult individuals (two males and two females) of $T$. pennipes were deposited in the collection of the Entomology Department, Faculty of Science, Cairo University (Efflatoun Bey's collection (EFC)), while the other 2 individuals ( 1 male and 1 female) were deposited in the Ministry of Agriculture Collection, Plant Protection Research Institute, Dokki, Giza (PPDD).

\section{Results and discussion Diagnosis of $T$. pennipes}

Adult about $10 \mathrm{~mm}$ in length, strikingly characterized by a peculiar row of flattened feather-like setae standing nearly erect on the outer side of the hind tibiae, and the longest of which are at least one-third the length of the tibia itself (Fig. 2); head velvety black; antennae, in resting position, are situated in the forehead in a cephalic depression, the antennal fossa; pedicel subcylindrical in shape; flagellum approximately triangular in cross section, densely covered with non-innervated microtrichia, with arista consisting of 2 short basal and a long distal segment, situated proximally on its dorsal side; prescutum including the humeral calli yellowish with four longitudinal velvety-black stripes; scutum blackish, merged with yellowish coloration that extended from the prescutum especially in males; scutellum of both sexes, black with yellowish tinge; wings in male mostly black with a hyaline posterior margin, having a pale ferruginous costal area (Fig. 2a), whereas in female, they are usually uniformly dusky or black, with the costal ferruginous marks sometimes occur (Fig. 2b); calypters large, yellowish in color; halteres large, yellowish; legs almost blackish with coxae, trochanters, and proximal portions of femora yellowish; pulvilli enlarged in males and small in females, buff colored; abdomen in males brightly reddish-orange, sometimes with a black tip, whereas in female it varies from completely black to orange with a black tip (Fig. 2).

\section{Taxonomy of the newly recorded taxa}

Subfamily Phasiinae

Tribe Gymnosomatini (new record from Egypt)

Genus Trichopoda Berthold 1827 (new record from Egypt)

Trichopoda Berthold 1827: 508 (as "Trichopode" (vernacular) by Latreille 1825: 498. Type species: Thereva plumipes Fabricius 1805, by subsequent designation of Coquillett (1910): 616)

Trichiopoda. Incorrect subsequent spelling of Trichopoda Berthold 1827 (Latreille 1829: 512)

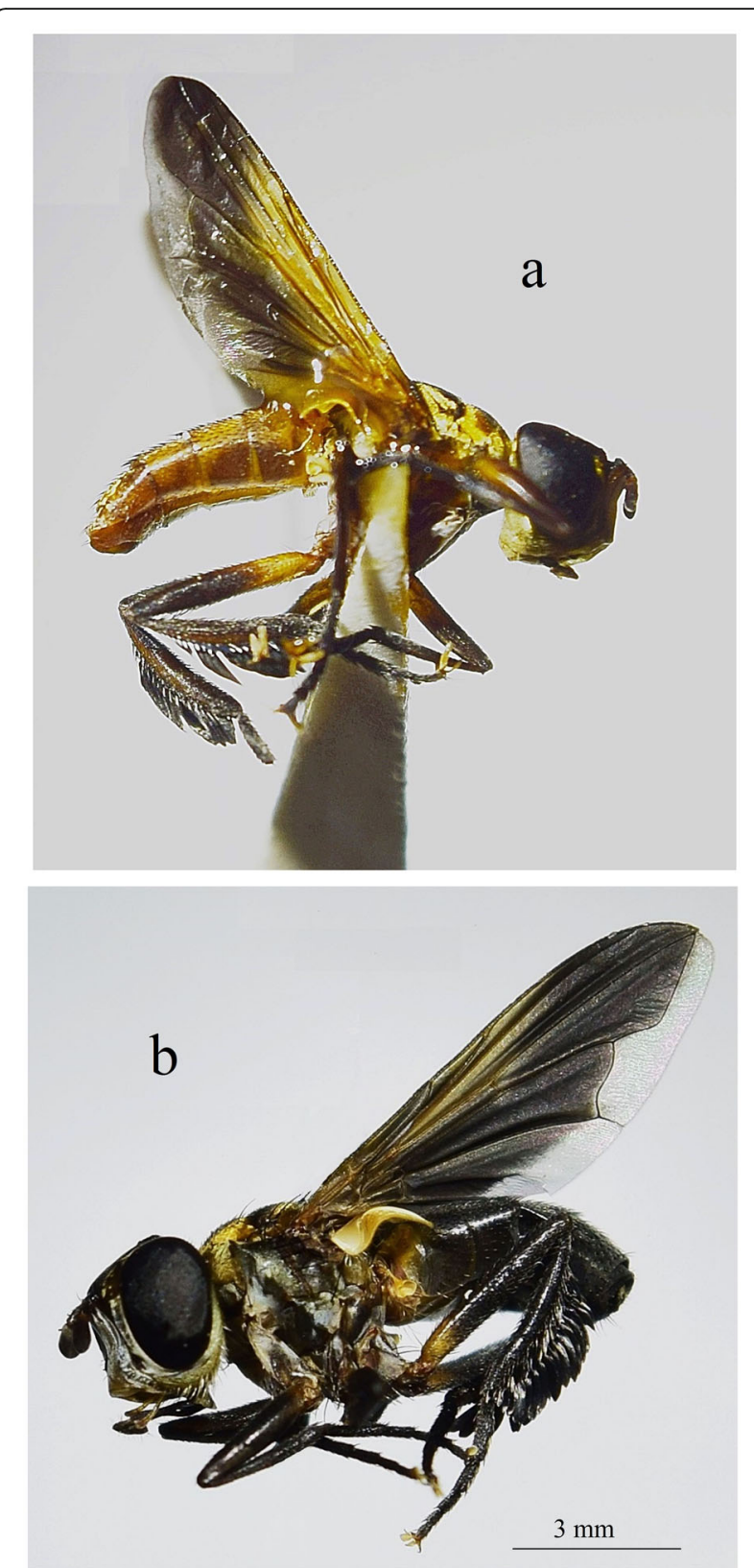

Fig. 2 Trichopoda pennipes (Fabricius), habitus. a Male. b Female

Trichopoda pennipes (Fabricius 1781) (new record from Egypt)

Musca pennipes Fabricius 1781: 450. Type locality: North America

Thereva hirtipes Fabricius 1805: 219. Type locality: USA (Carolina)

Thereva pennipes Fabricius 1805: 219 (junior secondary homonym of Musca pennipes Fabricius 1781). Type locality: USA (Carolina)

Phasia jugatoria Say 1829: 172. Type locality: USA (IN) 
Trichopoda cilipes Wiedemann 1830: 276 (a new replacement name for pennipes Fabricius 1805)

Trichopoda flavicornis Robineau-Desvoidy 1830: 284. Type locality: USA (Carolina)

World distribution: AU (introduced): Hawaiian Is. NE and NEO: native to both North and South America. PA (introduced): Egypt (new record), Israel, southern Europe (France, Italy, Spain, Slovenia, the Netherlands, Israel, Albania, Croatia, Hungary, Switzerland, Portugal)

Egyptian localities: lower Nile Valley and Delta: Giza (parasitoid of Nezara viridula)

Dates of collection: October to December

A list of other previously recorded Egyptian taxa of the subfamily Phasiinae (based on El-Hawagry 2018):

Tribe Cylindromyiini

Genus Besseria Robineau-Desvoidy 1830

Besseria anthophila (Loew 1871)

Egyptian localities: coastal strip: Dekhila, Mariout

Dates of collection: June to August

Genus Cylindromyia Meigen 1803

Cylindromyia intermedia (Meigen 1824)

Egyptian localities: coastal strip: Alexandria, Mariout,

Max, Ramleh. Upper Nile Valley: Beni Suef

Dates of collection: April to September

Cylindromyia rufipes (Meigen 1824)

Egyptian localities: coastal strip: Alexandria. Lower

Nile Valley and Delta: Gebel Asfar, Kubba

Dates of collection: October to February

Tribe Leucostomatini

Genus Dionomelia Kugler

Dionomelia hennigi Kugler, 1978

Egyptian localities: Sinai

Dates of collection: April to September

Genus Leucostoma Meigen

Leucostoma engeddense Kugler, 1966

Egyptian localities: lower Nile Valley and Delta: Minia

El-Qamh, Tanta

Dates of collection: February to May

Leucostoma obsidianum (Wiedemann 1830)

Egyptian localities: upper Egypt: Asswan

Dates of collection: unknown

Tribe Phasiini

Genus Phasia Latreille

Phasia pusilla Meigen 1824

Egyptian localities and dates of collection are not precisely known.

\section{Conclusion}

In Egypt, the feather-legged fly, T. pennipes, is newly detected to parasitize adults of the southern green stink bug, $N$. viridula. It seems to be established in Egypt. An effort should be done to assess the role of this parasitoid species in the biological pest control in Egypt.

\section{Abbreviations}

AF: Afrotropical; AU: Australasian; Is: Islands; NE: Nearctic; NEO: Neotropical; OR: Oriental; PA: Palearctic

\section{Acknowledgements}

We would like to thank Dr. Saeed Abol-Ela, Professor of Entomology at the Department of Economic Entomology and Pesticide at the Faculty of Agriculture, Cairo University, for his invaluable help and allowance for using the laboratory to conduct part of the present study.

Authors' contributions

All authors read and approved the final manuscript.

Funding

No funding

Availability of data and materials

Data supporting the conclusions of this article are presented in the main manuscript.

Ethics approval and consent to participate

Not applicable

Consent for publication

Not applicable

\section{Competing interests}

The authors declare that they have no competing interests.

\section{Author details}

${ }^{1}$ Entomology Department, Faculty of Science, Cairo University, Giza, Egypt. ${ }^{2}$ Classification Research Department, Plant Protection Research Institute, Agricultural Research Centre, Ministry of Agriculture, Dokki, Egypt. ${ }^{3}$ Department of Piercing and Sucking Insects, Plant Protection Research Institute, Agricultural Research Centre, Ministry of Agriculture, Dokki, Egypt.

Received: 21 December 2019 Accepted: 21 January 2020

Published online: 05 February 2020

References

Arnaud PH (1978) A host-parasite catalog of North American Tachinidae (Diptera). United States Department of agriculture. Misc Publ 1319:1-860

Bennett FD (1990) Potential for biological control of the stink bug, Nezara viridula, a pest of macadamias. Acta Hortic 275:679-684

Berthold AA (1827) Latreille's Natürliche Familien der Thierreichs. Aus dem Französischen. Mit Anmerkungen und Zusätzen, vol x. Landes-Industrie Comptoir, Weimar, p 606

Bystrowski C (2012) Thoughts on how Trichopoda pennipes (F.) reached Israel. Tachinid Times 25:13-15

Cargnus E, Buian FM, Zandigiacomo P (2011) Presenza di Trichopoda pennipes (Diptera, Tachinidae) nell'Italia nord-orientale. Bollettino della Soc Naturalisti «Silvia Zenari» 35:123-130

Clausen CP (1978) Introduced parasites and predators of arthropod pests and weeds: a world review. USDA Agricultural Handbook, p 545

Cock MJW (1985) A review of biological control of pests in the Commonwealth Caribbean and Bermuda up to 1982, technical communication no. 9. Commonwealth Institute of Biological Control, Commonwealth Agricultural Bureau, U.K., p 218

Colazza S, Giangiuliani G, Bin F (1996) Fortuitous introduction and successful establishment of Trichopoda pennipes F.: adult parasitoid of Nezara viridula (L. ). Biol Control 6:409-411

Coquillett DW (1910) The type-species of the North American genera of Diptera. Proc U S Natl Mus 37(1719):499-647

Davis CJ (1964) The introduction, propagation, liberation and establishment of parasites to control Nezara viridula variety smaragdina (Fabricius) in Hawaii (Heteroptera: Pentatomidae). Proc Hawaiian Entomol Soc 18:369-375

De Groot M, Virant-Doberlet M, Žunič A (2007) Trichopoda pennipes F. (Diptera, Tachinidae): a new natural enemy of Nezara viridula (L.). Slovenia: short communication. Agricultura 5(1):25-26 
El-Hawagry M (2017) Catalogue of Egyptian Tephritoidea (Diptera: Schizophora: Acalyptratae). Zootaxa 4299(2):151-190. https://doi.org/10.11646/zootaxa. 4299.2.1

El-Hawagry M, Gilbert F (2014) Zoogeographical affinities and faunal relationships of bee flies (Diptera: Bombyliidae) in Egypt. Zool Middle East 60(1):50-56. https://doi.org/10.1080/09397140.2014.892339

El-Hawagry MS (2018) Catalogue of the Tachinidae of Egypt (Diptera: Oestroidea). Egypt J Biol Pest Control 28:46. https://doi.org/10.1186/s41938-018-0042-3

Fabricius JC (1781) Species insectorum exhibentes eorum differentias specificas, synonyma, auctorum, loca natalia, metamorphosin, vol 2. C.E. Bohnii, Hamburg and Kiel, p 517

Fabricius JC (1805) Systema antliatorum secundum ordines, genera, species adiectis synonymis, locis, observationibus, descriptionibus. C. Reichard, Brunsvigae $[=$ Brunswick]. xiv + 15-372 + 30pp

Freidberg A, Morgulis E, Cerretti P (2011) The invasive species Trichopoda pennipes (F.) (Diptera: Tachinidae) found in Israel. Tachinid Times 24:14-15

Galerie-insecte (2015) Trichopoda - distribution en france métropolitaine. Available from: http://www.galerie-insecte.org/galerie/repartition.php?dep= 38\&gen=trichopoda. Accessed 1 Dec 2019

Kugler J (1966) Species of the genus Leucostoma (Tachinidae, Phasiinae) in Israel. Isr J Zool 15:173-182

Kugler J (1978) Leucostoma edentata n. sp. and Dionomelia hennigi n. gen., n. sp. , two new Leucostomatini from Israel (Diptera: Tachinidae: Phasiinae). Entomol Ger 4:344-348

Latreille PA (1825) Familles naturelles du règne animal, exposées succinctement et dans un ordre analytique, avec l'indication de leurs genres. J.-B. Baillière, Paris, p 570

Latreille PA (1829) Suite et fin des insectes. In: Cuvier GCLD, Le règne animal distribué d'après son organisation, pour servir de base a l'histoire naturelle des animaux et d'introduction a l'anatomie comparée. Avec figures dessinees d'après nature. Nouvelle édition, revue et augmentée, vol xxiv. Tome $\mathrm{V}$. Déterville \& Crochard, Paris, p 556

Loew H (1871) Beschreibung europäischer Dipteren. Zweiter Band. Systematische Beschreibung der bekannten europäischen zweiflügeligen Insecten. Von Johann Wilhelm Meigen. Neunter Theil oder dritter Supplementband, vol viii. H.W. Schmidt, Halle, p 319

Meigen JW (1803) Versuch einer neuen GattungsEintheilung der europäischen zweiflügligen Insekten. Mag Insekt 2:259-281

Meigen JW (1824) Systematische Beschreibung der bekannten europäischen zweiflügeligen Insekten, vol xii. Vierter Theil. Schulz-Wundermann, Hamm, p 428

Michael PJ (1981) Trichopoda: a tricky parasite. J Agric Western Australia, Series 4 22(2):56-57

O'Connor BA (1950) Trichopoda pennipes F. in Fiji and the British Solomon Islands. Fiji Agric J 21:63-71

Obrecht E (2014) Erstfunde von Trichopoda pennipes (Fabricius, 1781) (Diptera, Tachinidae) in der Schweiz, und eine Würdigung einer Amateurentomologin. Contrib Nat Hist 25:71-79

Peris SV (1998) Un Trichopodini (Diptera, Tachinidae, Phasiinae) en España. Bol R Soc Esp Hist Nat 94(1-2):163-164

Pétremand G, Rochefort S, Jaccard G, Fischer S (2015) First detection of the southern green stink bug parasitoid Trichopoda pennipes (Fabr.) (Diptera: Tachinidae) in western Switzerland. Mitt Schweiz Entomol Ges 88:403-409

Rice KB, Bergh CJ, Bergmann EJ, Biddinger DJ, Dieckhoff C, Dively G, Tooker JF (2014) Biology, ecology, and management of brown marmorated stink bug (Hemiptera: Pentatomidae). J Integr Pest Manag 5(3):1-13

Robineau-Desvoidy JB (1830) Essai sur les myodaires. Mém prés div Sav Acad Sci Inst Fr, Sér 2 2:1-813

Salerno G, Colazza S, Bin F (2002) Nezara viridula parasitism by the tachinid fly Trichopoda pennipes ten years after its accidental introduction into Italy from the New World. Biocontrol 47(6):617-624

Sándor N (2014) A parasitic Trichopoda fly killing southern green stink bugs arrives in Hungary. Available from: http://nagyelte.blogspot.de/2014/10/ trichopoda-pennipes-fly-parasitizing.html. Accessed 1 Dec 2019

Say T (1829) Descriptions of North American dipterous insects. Proc Acad Nat Sci Philadelphia 6(1829-1830):149-178

Todd JW (1989) Ecology and behavior of Nezara viridula. Annu Rev Entomol 34(1):273-292

Tschorsnig H-P, Cerretti P, Zeegers T (2012) Eight "alien" tachinids in Europe. Tachinid Times 25:11-13
Tschorsnig H-P, Zeegers T, Holstein J (2000) Further records of the introduced parasitoid Trichopoda pennipes (Fabricius, 1781) (Diptera, Tachinidae) from northeastern Spain and southern France. Bol R Soc Esp Hist Nat 96:215-216

Waterhouse DF (1998) Biological control of insect pests: Southeast Asian prospects. Aus Centre Int Agric Res Canberra vii:548

Waterhouse DF, Norris KR (1987) Biological Control, Pacific Prospects. Inkata, Melbourne, p 454

Wiedemann CRW (1830) Aussereuropäische zweiflügelige Insekten. Als Fortsetzung des Meigenschen Werkes, vol xii. Zweiter Theil. Schulz, Hamm, p 684

Worthley HN (1924) The biology of Trichopoda pennipes Fab. (Diptera, Tachinidae), a parasite of the common squash bug. Part 1. Psyche 31:7-16

Zeegers T (2010) Tweede aanvulling op de naamlijst van Nederlandse sluipvliegen (Diptera: Tachinidae). Nederl Faun Med 34:55-66

\section{Publisher's Note}

Springer Nature remains neutral with regard to jurisdictional claims in published maps and institutional affiliations.

\section{Submit your manuscript to a SpringerOpen ${ }^{\circ}$ journal and benefit from:}

- Convenient online submission

- Rigorous peer review

- Open access: articles freely available online

- High visibility within the field

- Retaining the copyright to your article

Submit your next manuscript at $>$ springeropen.com 